\title{
Effect of seasonal variations on the acid gelation of milk
}

Siqi Li, (๑) Aiqian Ye, ${ }^{*} \odot$ and Harjinder Singh $($ ๑)

Riddet Institute, Massey University, Private Bag 11 222, Palmerston North 4442, New Zealand

\begin{abstract}
We investigated the effect of seasonal variations on the acid gelation properties of bovine milk in a seasonal-calving New Zealand herd for 2 full milking seasons. We tested the formation of acid gels in 2 milk systems: unstandardized skim milk and standardized whole milk (4.6\% protein, $4.0 \%$ fat). For unstandardized skim milk, late-season milk acid gels had a longer gelation time and a lower gelation $\mathrm{pH}$ than early- and mid-season milk acid gels, but we found no consistent seasonal variation in the final storage modulus. For standardized milk, late-season milk had the most inferior acid gelation properties during the year, including the lowest final storage modulus, the lowest gelation $\mathrm{pH}$, and the longest gelation time. Standardization alleviated but did not eliminate the prolonged gelation time of late-season milk. These results indicated that the physicochemical properties of seasonal milk contributed greatly to its acid gelation, independent of differences in protein content. Standardization was not adequate to stabilize the acid gelation properties of late-season milk. Desirable acid gelation properties correlated with lower glycosylated $\kappa$-casein content, lower $\beta$-lactoglobulin: $\alpha$-lactalbumin ratio, lower extent of whey protein-casein micelle association, and lower total calcium and ionic calcium content. We discuss the possible effects of the correlating variables on the acid gelation properties of seasonal milk. Natural variations in the glycosylation degree of $\kappa$-casein might play an important role in acid gel structural development by altering the electrostatic and hydrophobic interactions among the milk proteins.
\end{abstract}

Key words: bovine milk, seasonal variation, acid milk gel, rheology, k-casein glycosylation

\section{INTRODUCTION}

Seasonal variations in the composition and properties of milk have been a challenge for the dairy industry

Received September 18, 2019.

Accepted February 10, 2020.

*Corresponding author: a.m.ye@massey.ac.nz in maintaining product quality over different seasons of the year. The extent of seasonal variation in milk characteristics is pronounced, particularly in countries such as New Zealand, Australia, and Ireland, where calving of most cows occurs at the same time of the year (late winter to spring). This synchronized calving practice results in a seasonal variation pattern that is largely controlled by the stage of lactation, because of its profound effect on milk composition and properties. Compared with the rest of the year, late-season milk from a seasonal-calving system has unique properties, including the highest protein and fat content, the lowest lactose content, and altered protein and salt composition (Auldist et al., 1995, 1998). Such variations in the composition and properties of milk result in considerable differences in its processing properties, and in the quality of dairy products (O'Brien and Guinee, 2011). For instance, the inferior cheesemaking properties of late-lactation milk have been demonstrated by previous studies (Lucey and Fox, 1992; Lucey, 1996; Hickey et al., 2006). For 2 main reasons, it is difficult to fully understand and control seasonal variations in dairy product quality. First, different milk characteristics change concurrently over the season, making it difficult to pinpoint the main contributor. Second, seasonal variation patterns might differ by herd or by year in the same herd, because of the influences of herd management, climate, health status of the cow, and other factors.

The acid gelation of milk is important for the production and quality of fermented dairy products, such as yogurt. The acidification of milk to the isoelectric point of caseins ( $\mathrm{pH} 4.6$ ) leads to destabilization of the casein micelles and gelation of the milk. Upon acidification, solubilization of the colloidal calcium phosphate and partial disintegration of the casein micelles occur before aggregation among the milk proteins (Heertje et al., 1985; Lucey and Singh, 1997; Donato et al., 2007). Typically, milk for yogurt-making is heated to 80 to $95^{\circ} \mathrm{C}$ for several minutes before acidification to induce a high level of whey protein denaturation. The denatured whey proteins participate in the acid gel structure, resulting in elevated gelation $\mathrm{pH}$, reduced gelation time, and a firmer gel structure compared with unheated milk (Lucey et al., 1998; Vasbinder et al., 2003; Lakemond and van Vliet, 2008). 
Standardization is a common practice in the dairy industry to control processing properties and the quality of dairy products such as yogurt. However, standardization does not account for variations in the physicochemical properties of milk and their potential effect on dairy products.

Limited published information on the seasonal or lactational variations in the acid gelation properties of milk is available. Underwood and Augustin (1997) reported that acid gels made with milk reconstituted from skim milk powders produced during the late season (March to May) in Australia had the lowest gel strength and the longest gelation time. However, to our knowledge, no published study has reported on acid milk gels made using fresh seasonal milk with standardization based on protein content.

The aim of this study was to investigate seasonal variations in the rheological properties of acid milk gels over 2 full milking seasons in a typical seasonal-calving New Zealand herd. Our previous work investigated natural seasonal variations in milk characteristics and their effects on heat-induced changes in milk ( $\mathrm{Li}$ et al., 2019). We determined the acid gelation properties of the same seasonal milk samples in the present study in 2 milk systems: unstandardized skim milk and standardized milk (4.6\% protein, $4.0 \%$ fat). We compared the 2 systems to determine the effectiveness of standardization in maintaining the acid gelation properties of seasonal milk throughout the year. A better understanding of acid gelation behavior will help to control the quality of yogurt and other fermented dairy products. In addition, variations in acid gelation properties may highlight differences in seasonal milk properties and provide new perspectives on acid gelation mechanisms.

\section{MATERIALS AND METHODS}

\section{Milk Sampling and Processing}

Seasonal milk was taken from Massey University No. 4 dairy farm for 2 full milking seasons from August 2016 to May 2018 as described in Li et al. (2019). The 2 milking seasons took place in the years 2016 to 2017 and 2017 to 2018. Early season, mid-season, and late season were defined as 8 to $100 \mathrm{~d}, 101$ to $220 \mathrm{~d}$, and 221 to $300 \mathrm{~d}$ of lactation, corresponding to August to October, November to February, and March to May in both years.

Fresh whole milk was pasteurized at $72^{\circ} \mathrm{C}$ for $15 \mathrm{~s}$ and skimmed using a centrifugal separator (model $103 \mathrm{AE}$; Alfa-Laval, Staffanstorp, Sweden) at $50^{\circ} \mathrm{C}$. Ultrafiltration of part of the skim milk was performed at $50^{\circ} \mathrm{C}$ on an HFK-131 membrane (observed separation range of
10 kDa; Koch Membrane Systems, Wilmington, MA), without diafiltration. The target protein content of the final UF retentate was $12 \%$.

Acid gelation analysis was conducted with 2 sample systems: unstandardized skim milk and standardized whole milk (4.6\% protein, $4.0 \%$ fat). A flowchart of milk processing and standardization is shown in Figure 1. The unstandardized skim milk was heated at $90^{\circ} \mathrm{C}$ for 6 min right after skimming, followed by cooling in ice water to $20^{\circ} \mathrm{C}$. The standardized milk was made by mixing skim milk, cream, and UF retentate (or permeate) in calculated ratios. Permeate was added instead of retentate only when the protein content of the skim milk was too high, to achieve $4.6 \%$ protein in the mixture. The standardized milk mixture was then homogenized at $70^{\circ} \mathrm{C}(13.79 \mathrm{MPa}$ in the first stage and $3.45 \mathrm{MPa}$ in the second stage) and heated at $90^{\circ} \mathrm{C}$ for $6 \mathrm{~min}$. After heating, the milk was immediately cooled to $20^{\circ} \mathrm{C}$ in ice water. The heated milk samples were stored at $4^{\circ} \mathrm{C}$ and analyzed within 2 days. Samples were preserved with $0.02 \%$ (wt/wt) sodium azide. Aliquots of samples were frozen at $-20^{\circ} \mathrm{C}$ before compositional analysis.

\section{Characterization of Milk Composition and Properties}

A MilkoScan FT120 (Foss Electric, Hillerød, Denmark) was used to determine the fat and protein content of the cream, UF retentate, and UF permeate, as well as the composition of the unstandardized skim milk and the standardized milk, including fat, protein, lactose, total solids, and nonfat solids.

Milk characterizations were performed as described in our previous work ( $\mathrm{Li}$ et al., 2019). The characterizations of raw milk included total calcium, inorganic phosphorus, $\mathrm{pH}$, ionic calcium $\left(\mathrm{Ca}^{2+}\right)$, ethanol stability (only in 2017-2018), buffering capacity (only in 20172018), casein micelle size, protein composition, and the glycosylation of $\kappa-\mathrm{CN}$. The extent of heat-induced $\kappa-\mathrm{CN}$ dissociation, whey protein denaturation, and whey protein-casein micelle association of heated unstandardized skim milk $\left(90^{\circ} \mathrm{C}, 6 \mathrm{~min}\right)$ were also determined. As well, $\mathrm{pH}, \mathrm{Ca}^{2+}$, and buffering capacity were determined for the heated standardized whole milk.

\section{Rheological Analysis of Acid Milk Gels}

Acid milk gels were made by acidification using glucono- $\delta$-lactone (GDL) and analyzed using an AR-G2 magnetic bearing rheometer (TA Instruments, Crawley, West Sussex, UK) with standard Peltier concentric cylinder geometries (including a cup and a rotor with radii of 15 and $14 \mathrm{~mm}$, respectively). Low-amplitude oscillation tests were performed using a method modified 
from Anema et al. (2004). Milk was warmed to $30^{\circ} \mathrm{C}$, $2.0 \%(\mathrm{wt} / \mathrm{vol})$ GDL was added, and the mixture was stirred for 2 min before analysis. Based on preliminary tests, measurements were taken for $6 \mathrm{~h}$ for unstandardized skim milk and for $8 \mathrm{~h}$ for standardized milk, allowing the storage modulus $\left(\mathbf{G}^{\prime}\right)$ to reach a stable level with a final $\mathrm{pH}$ of approximately 4.2. Gelation time was defined as the time from the addition of GDL to the time at which the $\mathrm{G}^{\prime}$ was greater than 1.0 Pa. The loss tangent of the final acid gel was determined. In 2017-2018, the $\mathrm{pH}$ changes during acidification were monitored simultaneously using a TitraLab 856 $\mathrm{pH}$-stat titration workstation (Radiometer Analytical, Lyon, France). The time differences for the addition of GDL, the measurements in the rheometer, and the measurements in the $\mathrm{pH}$-stat titrator were recorded to determine the actual gelation time, gelation $\mathrm{pH}$ (the $\mathrm{pH}$ at gelation time), and final $\mathrm{pH}$. Acid gelation analysis of each sample was at least duplicated. Acid gelation tests were conducted on 19 unstandardized skim milk and 15 standardized milk samples in 2016-2017, and 15 unstandardized skim milk and 15 standardized milk samples in 2017-2018 (4-8 samples in each season of each year).

\section{Statistical Analysis}

Statistical analysis was carried out on 3 to 8 results per season per year using SPSS version 24 (IBM Corp., Armonk, NY). We used 2-way ANOVA with the Tukey post hoc test to determine the overall effects of season, year, and their interactions. We analyzed the effect of seasonal variation in each year using 1-way ANOVA with the Tukey post hoc test and the effect of betweenyear variation in each season using independent samples $t$-tests. Pearson correlation coefficients were determined among milk and acid gel variables. The minimum level of statistical significance was $P<0.05$.

\section{RESULTS AND DISCUSSION}

\section{Milk Composition and Properties}

Table 1 shows the composition, buffering capacity, $\mathrm{pH}$, and $\mathrm{Ca}^{2+}$ content of unstandardized skim milks and standardized milks. Unstandardized skim milk from the late season had significantly lower lactose and higher protein, nonfat solids, and total solids than milk from the early and mid-season. As expected, the variation pattern of the composition of the skim milk followed the trend of seasonal whole milk ( $\mathrm{Li}$ et al., 2019). Standardized milk eliminated the variations in milk composition during different seasons and between the 2 years, except for lactose content in 2017-2018, but this did not actively contribute to the acid gelation induced by GDL. Standardization erased the elevated buffering capacity in late-season skim milk, presumably because of the strong contribution of proteins to the milk buffering capacity. The $\mathrm{pH}$ and $\mathrm{Ca}^{2+}$ content of heated unstandardized skim milk and standardized milk were broadly similar, both correlating well with the $\mathrm{pH}$ and $\mathrm{Ca}^{2+}$ content of raw milk (Li et al., 2019). In summary, standardization equalized the composition and buffering capacity of seasonal milk but did not change the $\mathrm{pH}$ and $\mathrm{Ca}^{2+}$ content substantially. This allowed for a fair comparison of the acid gelation properties of seasonal milk.

\section{Acid Gelation Properties}

Unstandardized Skim Milk. Table 2 shows the acid gelation properties of unstandardized skim milk. The seasonal trends in the final $G^{\prime}$ were different in the 2 years, as indicated by the significant interactions between seasonal and year effects $(P<0.01)$. In 2016-2017, acid gels made from early-season skim milk had significantly lower $\mathrm{G}^{\prime}$ than those made from midand late-season milk, but in 2017-2018, we found no

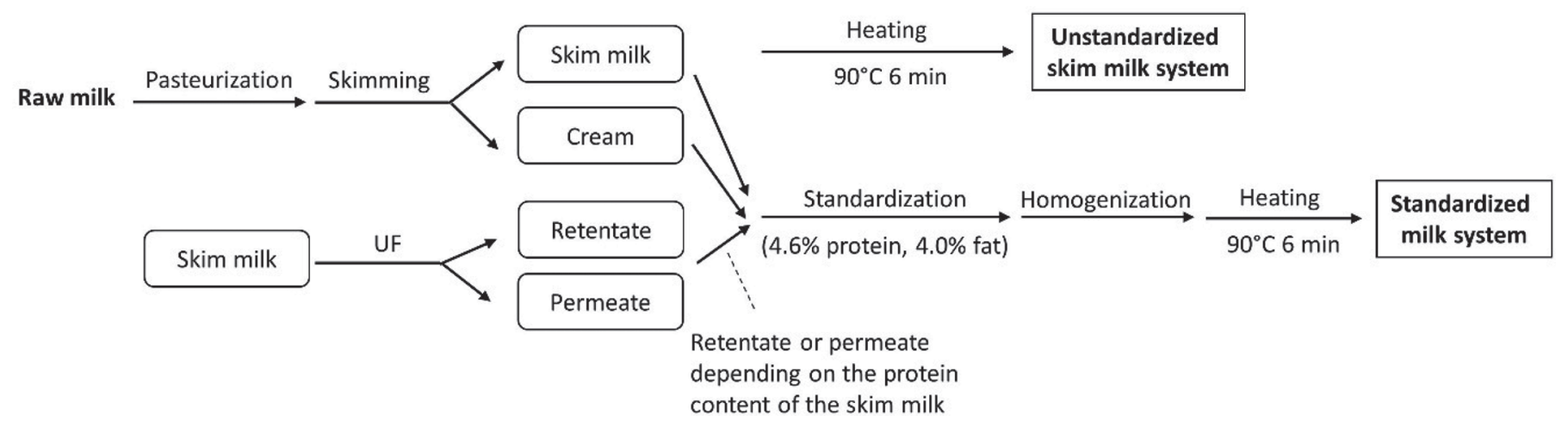

Figure 1. Flowchart of milk processing and preparation of sample systems. 
Table 1. Composition and chemical properties of unstandardized skim milk and standardized milk; values are given as means $\pm \mathrm{SE}^{1}$

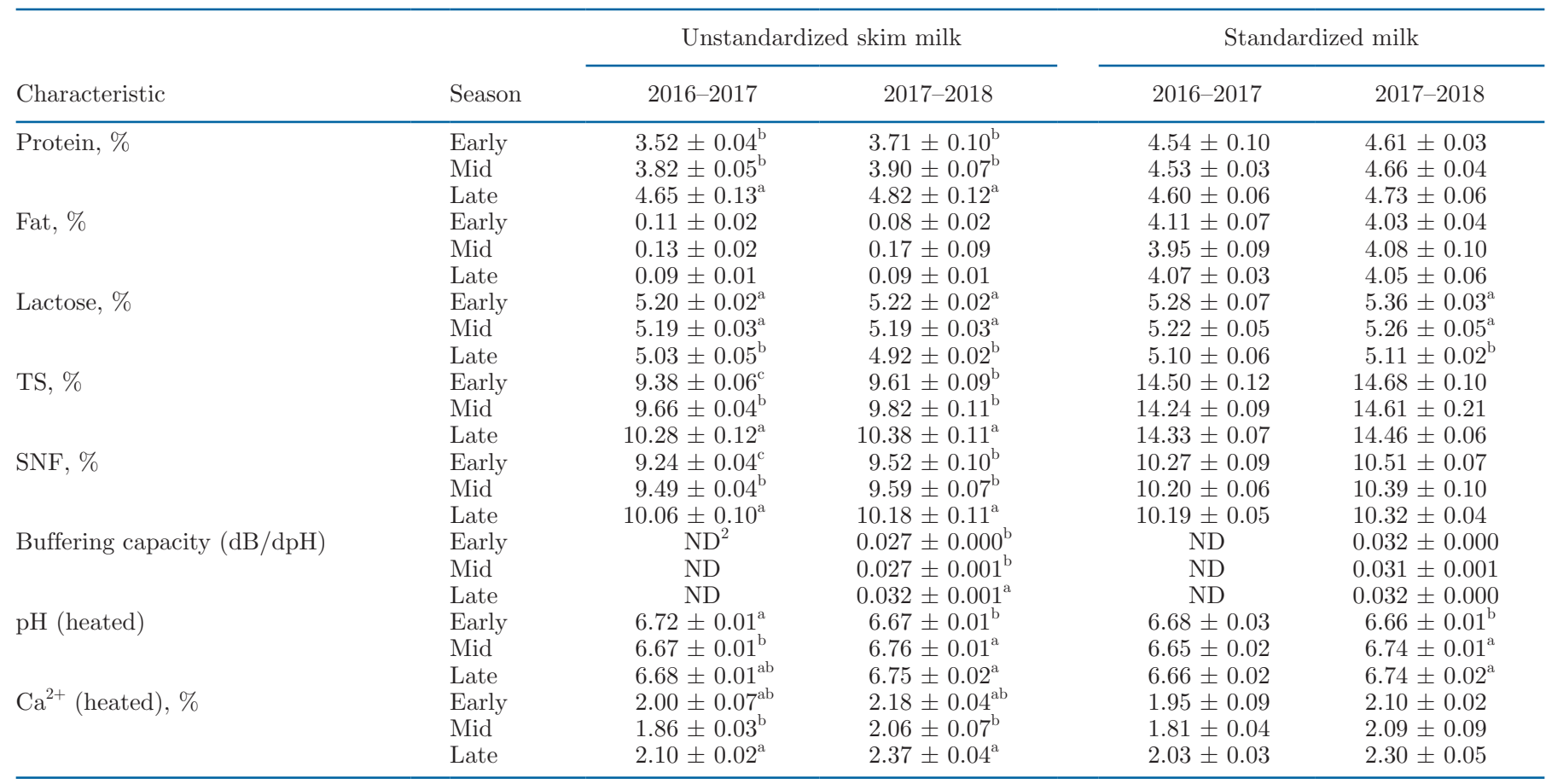

${ }^{\mathrm{a}-\mathrm{c}}$ Means of the same variable within a column with different superscripts differed $(P<0.05)$.

${ }^{1} \mathrm{Ca}^{2+}=$ ionic calcium.

${ }^{2} \mathrm{ND}=$ not determined.

significant seasonal difference in $\mathrm{G}^{\prime}$. It was interesting to note that although late-season milk had considerably higher protein content than early- and mid-season milk in both years (Table 1), late-season milk acid gels did not show higher $G^{\prime}$ than those in other seasons, except for the early season of 2016-2017. When we compared the 2 years, the mean $G^{\prime}$ values of acid gels made from mid- and late-season milk in 2017-2018 were lower than those in $2016-2017(P<0.05)$, despite similar milk protein content (Table 1). The gelation time was significantly longer in the late season than in the rest of the year, particularly in 2017-2018, when the mean gelation time of late-season milk was almost double that of early-season milk. The gelation time was longer in 2017-2018 than in 2016-2017 for all 3 seasons. The gelation pH results (2017-2018) echoed the seasonal variations in gelation time: late-season milk gelled at a significantly lower $\mathrm{pH}$ of 5.05 than early- and midseason milk (approximate $\mathrm{pH}$ 5.20). It is expected that milk with a lower gelation $\mathrm{pH}$ would take longer to form a gel during acidification. The extent of variation in the final loss tangents of the acid gels were not as large as those for the other gelation properties. Nevertheless, the final loss tangent was significantly higher, indicating less elastic or "solid-like" properties of the acid gels in the late season and in 2017-2018.
The results for the unstandardized skim milk acid gels suggested that the acid gelation properties of the milk were poor in the late season (among the seasons) and in 2017-2018 (between the 2 years). However, because of the differences in protein content, it is difficult to interpret these variations; for example, the higher protein contents of the late-season milks presumably increased the gelation time because of their higher buffering capacity (Table 1). Therefore, variations in the acid gelation properties of seasonal milk can be better understood by studying the standardized milk system.

Standardized Milk. Table 3 and Figure 2 show the acid gelation properties of standardized milk. The final $\mathrm{G}^{\prime}$ was significantly lower in the late season than in the early and mid-seasons, and this finding was consistent across both years. We found no significant betweenyear differences in the $\mathrm{G}^{\prime}$ of acid gels made in the early season or mid-season. However, the acid gels made in the late season of 2017-2018 had significantly lower G' than those made in the late season of 2016-2017. The seasonal and between-year variations in gelation $\mathrm{pH}$, gelation time, and final loss tangent were consistent with those of unstandardized skim milk.

Comparing the 2 sample systems, standardized milk gave rise to higher overall $\mathrm{G}^{\prime}$ and final loss tangent values, probably resulting from the higher protein con- 
Table 2. Acid gelation properties of unstandardized seasonal skim milk; values are given as means $\pm \mathrm{SE}^{1}$

\begin{tabular}{|c|c|c|c|c|c|c|}
\hline \multirow[b]{2}{*}{ Property } & \multirow[b]{2}{*}{ Season } & \multicolumn{2}{|c|}{ Means $\pm \mathrm{SE}$} & \multicolumn{3}{|c|}{ Effect $^{2}$} \\
\hline & & $2016-2017$ & $2017-2018$ & Season & Year & $\begin{array}{l}\text { Season } \\
\times \text { year }\end{array}$ \\
\hline $\begin{array}{l}\text { Gelation time, } \\
\text { min }\end{array}$ & $\begin{array}{l}\text { Early } \\
\text { Mid } \\
\text { Late }\end{array}$ & $\begin{array}{l}39.1 \pm 1.2^{\mathrm{a}, \mathrm{B}} \\
40.4 \pm 0.4^{\mathrm{a}, \mathrm{B}} \\
58.3 \pm 5.5^{\mathrm{b}, \mathrm{B}}\end{array}$ & $\begin{array}{l}43.9 \pm 1.39^{\mathrm{a}, \mathrm{A}} \\
48.6 \pm 2.62^{\mathrm{a}, \mathrm{A}} \\
81.9 \pm 7.59^{\mathrm{b}, \mathrm{A}}\end{array}$ & Late $>$ early, mid & $2017-2018>2016-2017$ & $P<0.05$ \\
\hline Gelation $\mathrm{pH}$ & $\begin{array}{l}\text { Early } \\
\text { Mid } \\
\text { Late }\end{array}$ & $\begin{array}{l}\mathrm{ND}^{3} \\
\mathrm{ND} \\
\mathrm{ND}\end{array}$ & $\begin{array}{l}5.22 \pm 0.29^{\mathrm{a}} \\
5.20 \pm 0.34^{\mathrm{a}} \\
5.05 \pm 0.37^{\mathrm{b}}\end{array}$ & Late $<$ early, mid & - & - \\
\hline Final LT & $\begin{array}{l}\text { Early } \\
\text { Mid } \\
\text { Late }\end{array}$ & $\begin{array}{l}0.254 \pm 0.001 \\
0.253 \pm 0.001 \\
0.257 \pm 0.002\end{array}$ & $\begin{array}{l}0.254 \pm 0.019^{\mathrm{a}} \\
0.256 \pm 0.023^{\mathrm{a}} \\
0.262 \pm 0.044^{\mathrm{b}}\end{array}$ & Late $>$ early, mid & $2017-2018>2016-2017$ & NS \\
\hline
\end{tabular}

\footnotetext{
${ }^{\mathrm{a}, \mathrm{b}}$ Means of the same variable within a column with different lowercase superscripts differed $(P<0.05,1$-way ANOVA).

${ }^{\mathrm{A}, \mathrm{B}}$ Means within a row with different uppercase superscripts differed $(P<0.05$, independent samples $t$-test).

${ }^{1} \mathrm{G}^{\prime}=$ storage modulus; $\mathrm{LT}=$ loss tangent.

${ }^{2}$ Analyzed using 2-way ANOVA.

${ }^{3} \mathrm{ND}=$ not determined.
}

tent of $4.6 \%$ compared with most unstandardized skim milk samples, and the involvement of homogenized milk fat in the mixture. In the early and mid-season, standardization was effective at stabilizing the $\mathrm{G}^{\prime}$ across seasons and between years. However, the late-season standardized milk acid gel had the lowest $\mathrm{G}^{\prime}$ of the 3 seasons in both years, a finding that was confounded in the unstandardized skim milk system by the highest protein content of the late-season milk.

Standardization did not alter gelation $\mathrm{pH}$ significantly $(P>0.1$ in all seasons). This indicated that it was not affected by the protein concentration of the system or the involvement of fat, but by the differences in physicochemical properties of the seasonal milk components.

By comparing the gelation times of the 2 milk systems over the seasons, we found that standardization alleviated the increase in gelation time in the late season. However, the gelation time of late-season standardized milk was still significantly higher than that of the milk from other seasons. The alleviation of the prolonged gelation time in late season by standardization probably resulted from the standardized protein content, and thus the standardized buffering capacity.

Table 3. Acid gelation properties of standardized milk; values are given as means $\pm \mathrm{SE}^{1}$

\begin{tabular}{|c|c|c|c|c|c|c|}
\hline \multirow[b]{2}{*}{ Property } & \multirow[b]{2}{*}{ Season } & \multicolumn{2}{|c|}{ Means $\pm \mathrm{SE}$} & \multicolumn{3}{|c|}{ Effect $^{2}$} \\
\hline & & $2016-2017$ & $2017-2018$ & Season & Year & $\begin{array}{l}\text { Season } \\
\times \text { year }\end{array}$ \\
\hline $\begin{array}{l}\text { Gelation time, } \\
\text { min }\end{array}$ & $\begin{array}{l}\text { Early } \\
\text { Mid } \\
\text { Late }\end{array}$ & $\begin{array}{l}38.7 \pm 1.0^{\mathrm{a}, \mathrm{B}} \\
38.0 \pm 0.3^{\mathrm{a}, \mathrm{B}} \\
49.7 \pm 2.3^{\mathrm{b}, \mathrm{B}}\end{array}$ & $\begin{array}{l}43.5 \pm 0.8^{\mathrm{a}, \mathrm{A}} \\
43.6 \pm 2.3^{\mathrm{a}, \mathrm{A}} \\
64.8 \pm 4.4^{\mathrm{b}, \mathrm{A}}\end{array}$ & Late $>$ early, mid & $2017-2018>2016-2017$ & $P<0.05$ \\
\hline Gelation $\mathrm{pH}$ & $\begin{array}{l}\text { Early } \\
\text { Mid } \\
\text { Late }\end{array}$ & $\begin{array}{l}\text { ND } \\
\text { ND } \\
\text { ND }\end{array}$ & $\begin{array}{l}5.29 \pm 0.04^{\mathrm{a}} \\
5.26 \pm 0.04^{\mathrm{a}} \\
5.07 \pm 0.04^{\mathrm{b}}\end{array}$ & Late $<$ early, mid & - & - \\
\hline Final LT & $\begin{array}{l}\text { Early } \\
\text { Mid } \\
\text { Late }\end{array}$ & $\begin{array}{l}0.225 \pm 0.001^{\mathrm{B}} \\
0.226 \pm 0.002^{\mathrm{B}} \\
0.229 \pm 0.001^{\mathrm{B}}\end{array}$ & $\begin{array}{l}0.230 \pm 0.001^{\mathrm{a}, \mathrm{A}} \\
0.234 \pm 0.001^{\mathrm{b}, \mathrm{A}} \\
0.233 \pm 0.000^{\mathrm{b}, \mathrm{A}}\end{array}$ & Late $>$ early & $2017-2018>2016-2017$ & NS \\
\hline
\end{tabular}

\footnotetext{
${ }^{\mathrm{a}, \mathrm{b}}$ Means of the same variable within a column with different lowercase superscripts differed $(P<0.05,1$-way ANOVA).

${ }^{\mathrm{A}, \mathrm{B}}$ Means within a row with different uppercase superscripts differed $(P<0.05$, independent samples $t$-test).

${ }^{1} \mathrm{G}^{\prime}=$ storage modulus; $\mathrm{LT}=$ loss tangent $\mathrm{ND}=$ not determined.

${ }^{2}$ Analyzed using 2-way ANOVA.
} 
The buffering capacity of skim milk was highest in the late season, whereas that of standardized milk did not vary with the season (Table $1, P=2.27$ ).

Analysis of the acid gelation property in a standardized milk system highlighted the overall inferior acid gelation properties of late-season milk, including the lowest $\mathrm{G}^{\prime}$, the longest gelation time, and the lowest gelation $\mathrm{pH}$. Our findings agreed with those of Underwood and Augustin (1997), who reported that acid gels made from late-season reconstituted milk in Australia had the lowest gel strength, the longest gelation time, and the highest final loss tangent (i.e., the least solid-like properties). It is also worth noting that these authors reconstituted the milk based on total solids content and that late-season milk powders had the highest protein content during the season. Consequently, the late-season reconstituted milk had the highest protein content but the worst gelation properties, consistent with our findings, particularly in 2017-2018 (Table 2 and Table 3). In agreement with Nguyen et al. (2018), we found that differences in acid gelation properties were greatly affected by the physicochemical properties of the milk components, independent of the differences in protein content. Standardization was not sufficient to stabilize the acid gelation properties of milk over the year in a seasonal-calving system.

\section{Correlation and Interpretation}

Table 4 shows the significant correlations between the acid gelation properties of standardized milk and the milk characteristics. The data we used for the seasonal milk characteristics in the correlation analysis were adapted from our previous work ( $\mathrm{Li}$ et al., 2019). In brief, the total calcium content of raw milk was highest in the late season. The $\mathrm{Ca}^{2+}$ content of the milk was lower in mid-season than in the early and late seasons. For protein composition, we found no significant seasonal variation in the ratio of casein to total protein. However, the content of glycosylated $(\mathbf{G})$ - $\kappa$-casein and the degree of glycosylation of $\kappa$-CN (GD, the percentage of $\mathrm{G}-\kappa-\mathrm{CN}$ in total $\kappa-\mathrm{CN}$ ) were highest in the late season, and the content of $\alpha$-LA was lowest in the late season. Upon heating at $90^{\circ} \mathrm{C}$ for 6

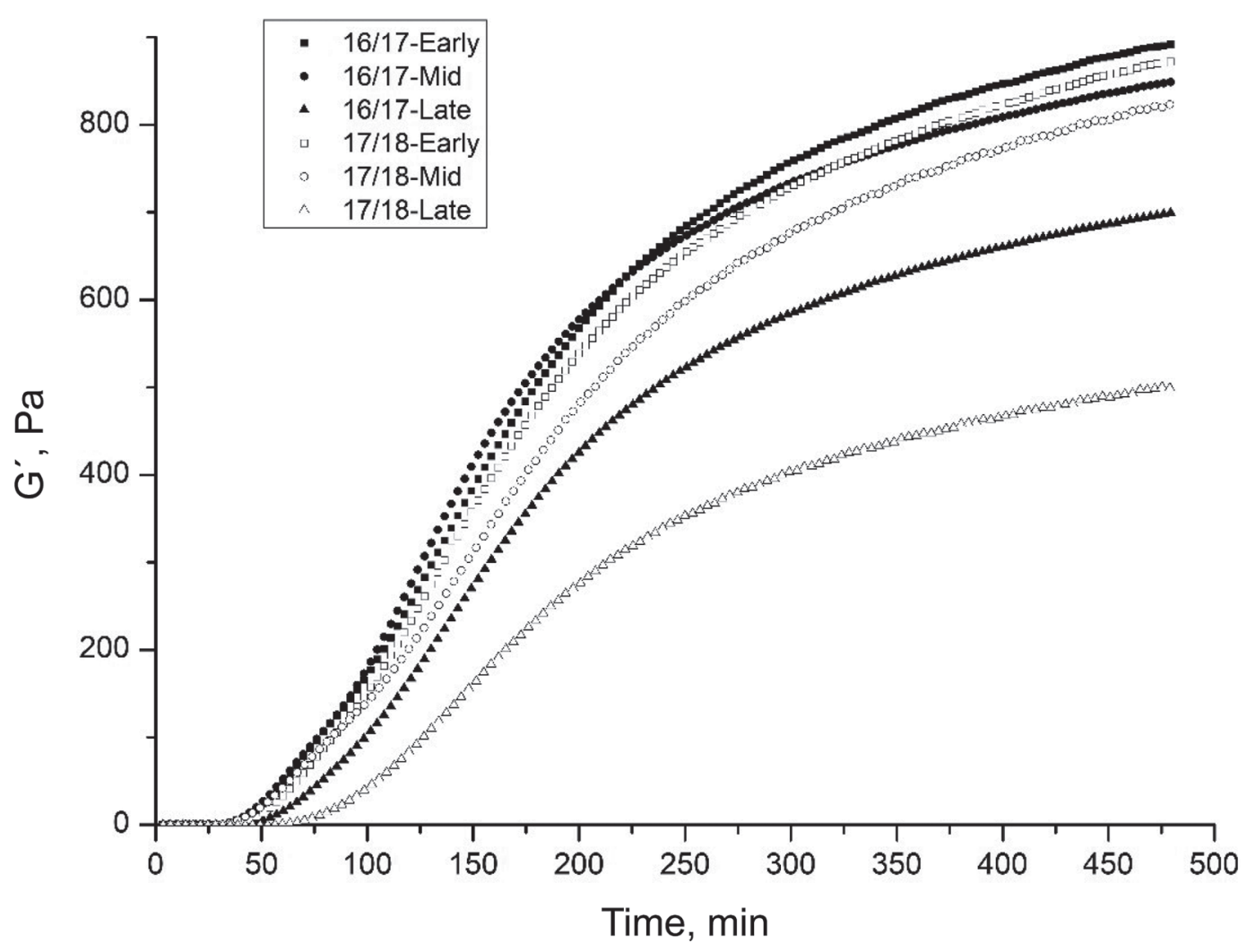

Figure 2. Change in storage modulus $\left(\mathrm{G}^{\prime}\right)$ with acidification time for acid gels made from standardized milks from the early season of the year 2016-2017 (16/17, $\mathbf{\square})$; the mid-season of the year 2016-2017 (16/17, •); the late season of the year 2016-2017 (16/17, $\mathbf{\Delta})$; the early season of the year 2017-2018 $(17 / 18, \square)$; the mid-season of the year 2017-2018 $(17 / 18, \bigcirc)$; and the late season of the year 2017-2018 $(17 / 18, \Delta)$. 
min, late-season milk had the highest extent of whey protein denaturation and the highest level of whey protein-casein micelle association.

Desirable acid gelation properties (i.e., higher gel strength, shorter gelation time, and higher gelation $\mathrm{pH})$ correlated with higher $\alpha-\mathrm{LA}$ content, lower total calcium, $\mathrm{Ca}^{2+}, \kappa-\mathrm{CN}, \mathrm{G}-\kappa-\mathrm{CN}$, and $\beta-\mathrm{LG}$ content, as well as with lower levels of heat-induced whey protein denaturation and whey protein-casein micelle association. When interpreting these correlations, it should be noted that the seasonal variations in acid gelation properties resulted from the combined effects of various milk characteristics that changed concurrently during the season. Because some of the milk quality variables were interrelated, they might not have affected the gelation properties to the extent that the correlations would suggest. Therefore, it is important to interpret these correlations with theoretical underpinnings. Four aspects of seasonal milk properties and their potential effects on the acid gelation properties of seasonal milk are discussed below: glycosylation of $\kappa-\mathrm{CN}$; heat-induced whey protein denaturation and association with casein micelles; the ratio of $\alpha$-LA to $\beta-\mathrm{LG}$; and calcium and $\mathrm{Ca}^{2+}$ content. The interrelations among these variables are also discussed.

Glycosylation of $\kappa-C N$. Glycosylated $\kappa-\mathrm{CN}$ content, which was highest in late-season milk in both years, had the highest correlation coefficients with lower $\mathrm{G}^{\prime}$ and longer gelation time among the standardized milk acid gels for all variables determined (Table $4, P$ $<0.001)$. In contrast, nonglycosylated $\kappa-\mathrm{CN}$ correlated with higher $\mathrm{G}^{\prime}$, high gelation $\mathrm{pH}$, and shorter gelation time $(P<0.05)$. This finding agreed with Cases et al. (2003), who demonstrated that the deglycosylation of $\kappa-\mathrm{CN}$ with neuraminidase resulted in higher acid gel firmness and shorter gelation time. The authors attributed the enhanced acid gelation properties to the higher surface hydrophobicity of the deglycosylated casein micelles. In a recent study, Oka et al. (2018) reported that $\kappa$-CN-depleted casein micelles had a higher acid gelation $\mathrm{pH}$ than native casein micelles because of their lower sialic acid content, higher surface hydrophobicity, and lower negative charge.

We know that $\kappa-\mathrm{CN}$ forms the surface layer of casein micelles, stabilizing the micelles by providing electrostatic and steric repulsion. Because of their importance in the stabilization of casein micelles, even minor changes in the properties of $\kappa-\mathrm{CN}$ could have a significant effect on casein micelle interactions. Glycosylated $\kappa-\mathrm{CN}$ carries hydrophilic sugar moieties that both increase the negative charge and reduce the hydrophobicity of $\kappa$-CN (Vreeman et al., 1977; Holland and Boland, 2014). Upon the acidification of milk, the added negative charge on the surface of the micelles by glycosylation might provide stronger resistance to charge neutralization. As such, a higher proportion of G- $\kappa-C N$ might lower the $\mathrm{pH}$ required for micelle aggregation and delay gelation. Subsequently, a longer gelation time would shorten the time available for the development of the gel structure, resulting in a lower $\mathrm{G}^{\prime}$ of the final gel. In addition, a higher concentration of $\kappa-\mathrm{CN}$, particularly $\mathrm{G}-\kappa-\mathrm{CN}$ (both highest in the late season), might reduce the hydrophobicity of the protein matrix, weakening the hydrophobic interactions in the acid gel network. The importance of hydrophobic interactions in the development of acid milk gel structure has been well established (Jean et al., 2006; Donato and Guyomarc'h, 2009; Morand et al., 2012).

In addition to variations in the GD of $\kappa-\mathrm{CN}$ of milk, the serum-to-milk ratio of the GD of $\kappa-\mathrm{CN}$ in heated

Table 4. Pearson correlation coefficients between seasonal milk characteristics and acid gelation properties of standardized milk ${ }^{1}$

\begin{tabular}{|c|c|c|c|c|}
\hline Characteristic/property & $\mathrm{G}^{\prime}$ & $\begin{array}{l}\text { Gelation } \\
\text { pH }\end{array}$ & $\begin{array}{l}\text { Gelation } \\
\text { time }\end{array}$ & Final LT \\
\hline$\kappa-\mathrm{CN}$ & $-0.759^{* * *}$ & $-0.567^{*}$ & $0.762^{* * *}$ & $0.582^{* *}$ \\
\hline Glycosylated $\kappa-\mathrm{CN}$ & $-0.920 * * *$ & $-0.792^{* * *}$ & $0.897 * * *$ & $0.506^{* *}$ \\
\hline Nonglycosylated $\kappa-\mathrm{CN}$ & $0.579^{*}$ & $0.664^{* *}$ & $-0.709 * *$ & NS \\
\hline$\kappa-\mathrm{CN}$ GD & $-0.927^{* * *}$ & $-0.834^{* * *}$ & $0.883^{* * *}$ & $0.429^{*}$ \\
\hline $\begin{array}{l}\text { Serum:milk } \kappa-C N \text { GD ratio } \\
\text { of heated milk }\end{array}$ & $0.768^{* * *}$ & $0.541^{*}$ & $-0.705^{* * *}$ & $-0.515^{* *}$ \\
\hline$\alpha-\mathrm{LA}$ & $0.890^{* * *}$ & $0.759 * *$ & $-0.722 * * *$ & NS \\
\hline$\beta-\mathrm{LG}$ & $-0.609^{* * *}$ & $-0.646^{* *}$ & $0.598^{* *}$ & $0.533^{* *}$ \\
\hline Whey protein denaturation & $-0.609^{* * *}$ & $-0.716^{* *}$ & $0.516^{* *}$ & NS \\
\hline Whey protein-casein micelle association & $-0.651^{* * *}$ & $-0.733^{* *}$ & $0.671^{* * *}$ & $0.453^{*}$ \\
\hline Total calcium & $-0.593^{* *}$ & $-0.770^{* * *}$ & $0.752^{* * *}$ & $0.685^{* * *}$ \\
\hline $\mathrm{Ca}^{2+}$, raw milk & $-0.463^{*}$ & $-0.859^{* * *}$ & $0.728^{* * *}$ & $0.518^{* *}$ \\
\hline $\mathrm{Ca}^{2+}$, standardized and heated milk & $-0.552^{* *}$ & $-0.786^{* * *}$ & $0.733^{* * *}$ & $0.473^{* *}$ \\
\hline
\end{tabular}


milk $\left(90^{\circ} \mathrm{C}\right.$ for $\left.6 \mathrm{~min}\right)$ was correlated with positive acid gelation properties. A lower serum-to-milk $\kappa$-CN GD ratio, as in late-season milk, indicates that a higher proportion of $\mathrm{G}-\kappa-\mathrm{CN}$ remained on the micelle surface than in the serum phase. As such, the GD of micellebound $\kappa-\mathrm{CN}$ was even higher than the GD of total $\kappa-\mathrm{CN}$ in late-season milk, and this may have further promoted the negative effects of $\kappa$-CN glycosylation on the acid gelation properties of milk. Further investigation is needed to test this hypothesis.

We propose that the amount of G- $\mathrm{k}-\mathrm{CN}$ played an important role in affecting the acid gelation properties of seasonal milk based on the consistent and strong correlations supported by previous work and by theoretical understanding. Variations in the distribution of G- $\kappa-\mathrm{CN}$ between the micelle and the serum phase might further amplify the effect of $\kappa-\mathrm{CN}$ glycosylation on the acid gelation properties of milk.

Whey Protein Denaturation and Association with Casein Micelles. The extent of heat-induced whey protein denaturation and the extent of whey protein-casein micelle association, both highest in lateseason milk, were correlated with lower $\mathrm{G}^{\prime}$ and longer gelation time (Table 4). The negative correlations between the extent of denaturation of whey proteins and desirable acid gelation properties were expected, given the high extent of whey protein denaturation and its small amount of variation in the heated milks in this study $(94.9 \pm 0.3 \%)$. In most samples, $\beta$-LG was completely denatured and the variation in total whey protein denaturation arose mostly from variations in the extent of denaturation of $\alpha$-LA. Compared with $\beta-L G$, denatured $\alpha$-LA does not contribute to the acid gel structure in the same way because of its lack of a free thiol group (Graveland-Bikker and Anema, 2003), lower isoelectric point (Paulsson et al., 1986), and lower hydrophobicity (Mottar et al., 1989; Morand et al., 2011). As a result, variations in the extent of whey protein denaturation, although statistically significant, might not greatly affect the acid gelation of milk.

Similar to whey protein denaturation, the higher extent of whey protein-casein micelle association, as in late-season milk, was correlated with inferior gelation properties. This finding agreed with those of several other researchers; that is, the soluble whey protein aggregates in heated milk contributed more to the acid gel structure than the micelle-bound whey proteins (Anema et al., 2004; Vasbinder et al., 2004; Lakemond and van Vliet, 2008; Anema, 2018). Anema (2008) emphasized the role of soluble whey protein aggregates in interconnecting colloidal casein particles with disulfide bonds, suggesting that the inter-particle disulfide bonds would give rise to a higher gel rigidity compared with the disulfide bonds on the individual micelles.
Ratio of $\alpha-L A$ to $\beta-L G$. A higher percentage of $\alpha$-LA and a lower percentage of $\beta$-LG in the milk proteins was correlated with better acid gelation properties (Table 4). These correlations contradicted the findings reported by Graveland-Bikker and Anema (2003), who demonstrated that the addition of $\beta-L G$ to wheyprotein-depleted milk resulted in significantly higher $\mathrm{G}^{\prime}$, higher gelation $\mathrm{pH}$, and shorter gelation time of acid gels compared with the addition of a mixture of $\alpha$-LA and $\beta$-LG (1:2 ratio) or $\alpha$-LA alone at the same concentration. This discrepancy was understandable considering that $\alpha$-LA made up only $2.6 \%$ of the total protein and $17.3 \%$ of the whey proteins in the present study, compared with the study of Graveland-Bikker and Anema (2003), in which $\alpha$-LA made up at least $33.3 \%$ of the added whey proteins. We found that $\beta$-LG had a rather small extent of variation (CV 7.1\%) and did not vary significantly by season in 2016-2017 (Li et al., 2019). Despite this insignificant seasonal variation in $\beta$-LG content in 2016-2017, late-season milk from 2016-2017 still had significantly worse acid gelation properties than the milks from the rest of the year. It was likely that the variation in the ratio of $\alpha$-LA to $\beta$-LG in itself did not contribute greatly to the variation in the acid gelation properties of the seasonal milks in this study.

Milk Calcium. The concentrations of both calcium and $\mathrm{Ca}^{2+}$ were correlated with lower $\mathrm{G}^{\prime}$, longer gelation time, and higher final loss tangent of the acid gels (Table 4). Underwood and Augustin (1997) also reported that late-season reconstituted milk had the highest $\mathrm{Ca}^{2+}$ content and the worst acid gelation properties. Some studies have shown that moderate calcium removal or its chelation by trisodium citrate improved the acid gel or yogurt properties (Ozcan-Yilsay et al., 2007; Meletharayil et al., 2015). Ozcan-Yilsay et al. (2007) reported that partial removal of the colloidal calcium phosphate by trisodium citrate before acidification gave rise to a higher level of protein rearrangement during the gelation process, resulting in a stronger gel network. However, reports on the effect of calcium on the acid gelation of milk have been contradicting. Ozcan et al. (2008) did not find a positive effect of another calciumchelating agent (tetrasodium pyrophosphate) on yogurt firmness. Ramasubramanian et al. (2008) reported only a minor effect of calcium addition or removal before heating on yogurt structural properties. Morand et al. (2011) suggested that $\mathrm{Ca}^{2+}$ binding did not affect the acid gel structure. In addition, the extents of natural variation in calcium and $\mathrm{Ca}^{2+}$ in the present study were markedly smaller than the adjusted levels in previous studies. The effect of natural variation in milk calcium on the rheological properties of acid milk gels is inconclusive until further, detailed investigations are made. 


\section{Interrelations Among Milk Quality Variables}

The GD of $\kappa$-CN was correlated $(P<0.001)$ with all variables discussed above that had significant correlations with acid gelation properties: lower $\alpha$-LA, higher $\beta$-LG, higher total calcium and $\mathrm{Ca}^{2+}$, and higher extents of heat-induced whey protein denaturation and association with the casein micelles. In addition, a higher proportion of $\beta$-LG in the total whey proteins and a higher $\mathrm{Ca}^{2+}$ content have been demonstrated to enhance the extent of whey protein denaturation and the extent of whey protein-casein micelle association (Oldfield, 1996; Law and Leaver, 2000; Li et al., 2019). Considering these interrelations, we conclude that the extent of heat-induced whey protein-casein micelle association might play a part in affecting the acid gelation properties of seasonal milk, but its effect is confounded to some extent by its correlation with the GD of $\kappa-\mathrm{CN}$. The variations in the denaturation of whey proteins, the ratio of $\alpha-\mathrm{LA}$ to $\beta-\mathrm{LG}$, and the calcium and $\mathrm{Ca}^{2+}$ content might not have strong direct effects on the acid gelation of seasonal milk. Their correlations with acid gelation properties were probably caused by their correlations with the GD of $\kappa-\mathrm{CN}$ and with the distribution of the denatured whey proteins between the micelles and the serum phase.

\section{CONCLUSIONS}

The acid gelation properties of seasonal milk deteriorated consistently in the late season of both years evaluated. By comparing unstandardized skim milk and standardized milk, we demonstrated that the inferior acid gelation properties of late-season milk resulted from its unique physicochemical properties, independent of the differing protein content. Standardization alleviated the elevated gelation time in the late season, but it was still significantly longer than the gelation time in early and mid season. In addition, standardized milk from the late season had the lowest acid gelation $\mathrm{pH}$ and the lowest $\mathrm{G}^{\prime}$ during the year. Standardization of the protein and fat content was not sufficient to stabilize the acid gelation properties throughout the year. Inferior gelation properties correlated significantly with GD of $\kappa-\mathrm{CN}$, heat-induced whey protein denaturation and whey protein-casein micelle association, ratio of $\alpha-\mathrm{LA}$ to $\beta$-LG, and calcium and $\mathrm{Ca}^{2+}$ content. Based on strong correlations and consistent literature reports, we propose that the glycosylation of $\kappa$-CN plays an important role in milk acid gelation by altering hydrophobic and electrostatic interactions. From the present study, it is difficult to draw a firm conclusion about how other variables affect acid gelation because of their interrelations and the lack of consistent supporting evidence.

\section{ACKNOWLEDGMENTS}

This study was funded by the Callaghan Innovation (Wellington, New Zealand). We thank Claire Woodhall (Havelock North, New Zealand) for proofreading the manuscript. The authors declare no conflict of interest.

\section{REFERENCES}

Anema, S. 2008. Effect of milk solids concentration on the gels formed by the acidification of heated $\mathrm{pH}$-adjusted skim milk. Food Chem. 108:110-118. https://doi.org/10.1016/j.foodchem.2007.10.051.

Anema, S. G. 2018. Effect of whey protein addition and $\mathrm{pH}$ on the acid gelation of heated skim milk. Int. Dairy J. 79:5-14. https:// doi.org/10.1016/j.idairyj.2017.11.008.

Anema, S. G., S. K. Lee, E. K. Lowe, and H. Klostermeyer. 2004. Rheological properties of acid gels prepared from heated pH-adjusted skim milk. J. Agric. Food Chem. 52:337-343. https://doi.org/10 $.1021 /$ jf034972c.

Auldist, M., S. Coats, G. Rogers, and G. McDowell. 1995. Changes in the composition of milk from healthy and mastitic dairy cows during the lactation cycle. Anim. Prod. Sci. 35:427-436. https:// doi.org/10.1071/EA9950427.

Auldist, M. J., B. J. Walsh, and N. A. Thomson. 1998. Seasonal and lactational influences on bovine milk composition in New Zealand. J. Dairy Res. 65:401-411. https://doi.org/10.1017/ S0022029998002970.

Cases, E., V. Vidal, and J. Cuq. 2003. Effect of k-casein deglycosylation on the acid coagulability of milk. J. Food Sci. 68:2406-2410. https://doi.org/10.1111/j.1365-2621.2003.tb07037.x.

Donato, L., M. Alexander, and D. G. Dalgleish. 2007. Acid gelation in heated and unheated milks: Interactions between serum protein complexes and the surfaces of casein micelles. J. Agric. Food Chem. 55:4160-4168. https://doi.org/10.1021/jf063242c.

Donato, L., and F. Guyomarc'h. 2009. Formation and properties of the whey protein/ $\kappa$-casein complexes in heated skim milk-A review. Dairy Sci. Technol. 89:3-29. https://doi.org/10.1051/dst:2008033.

Graveland-Bikker, J. F., and S. G. Anema. 2003. Effect of individual whey proteins on the rheological properties of acid gels prepared from heated skim milk. Int. Dairy J. 13:401-408. https://doi.org/ 10.1016/S0958-6946(02)00190-5.

Heertje, I., J. Visser, and P. Smits. 1985. Structure formation in acid milk gels. Food Structure 4:10.

Hickey, D. K., K. N. Kilcawley, T. P. Beresford, E. M. Sheehan, and M. G. Wilkinson. 2006. The influence of a seasonal milk supply on the biochemical and sensory properties of Cheddar cheese. Int. Dairy J. 16:679-690. https://doi.org/10.1016/j.idairyj.2005.10.017.

Holland, J. W., and M. J. Boland. 2014. Post-translational modifications of caseins. Pages 141-168 in Milk Proteins: From Expression to Food. 2nd ed. H. Singh, M. Boland, and A. Thompson, ed. Academic Press, San Diego, CA.

Jean, K., M. Renan, M.-H. Famelart, and F. Guyomarc'h. 2006. Structure and surface properties of the serum heat-induced protein aggregates isolated from heated skim milk. Int. Dairy J. 16:303-315. https://doi.org/10.1016/j.idairyj.2005.04.001.

Lakemond, C. M., and T. van Vliet. 2008. Acid skim milk gels: The gelation process as affected by preheating pH. Int. Dairy J. 18:574584. https://doi.org/10.1016/j.idairyj.2007.11.001.

Law, A. J., and J. Leaver. 2000. Effect of pH on the thermal denaturation of whey proteins in milk. J. Agric. Food Chem. 48:672-679. https://doi.org/10.1021/jf981302b.

Li, S., A. Ye, and H. Singh. 2019. Seasonal variations in composition, properties, and heat-induced changes in bovine milk in a seasonal calving system. J. Dairy Sci. 102:7747-7759. https://doi.org/10 $.3168 /$ jds.2019-16685.

Lucey, J. A. 1996. Cheesemaking from grass based seasonal milk and problems associated with late-lactation milk. Int. J. Dairy Technol. 49:59-64. https://doi.org/10.1111/j.1471-0307.1996.tb02491.x. 
Lucey, J. A., and P. F. Fox. 1992. Rennet coagulation properties of late-lactation milk: Effect of $\mathrm{pH}$ adjustment, addition of $\mathrm{CaCl}_{2}$, variation in rennet level and blending with mid-lactation milk. Ir. J. Agric. Food Res. 31:173-184.

Lucey, J. A., and H. Singh. 1997. Formation and physical properties of acid milk gels: A review. Food Res. Int. 30:529-542. https://doi .org/10.1016/S0963-9969(98)00015-5.

Lucey, J. A., M. Tamehana, H. Singh, and P. A. Munro. 1998. Effect of interactions between denatured whey proteins and casein micelles on the formation and rheological properties of acid skim milk gels. J. Dairy Res. 65:555-567. https://doi.org/10.1017/ S0022029998003057.

Meletharayil, G. H., H. A. Patel, and T. Huppertz. 2015. Rheological properties and microstructure of high protein acid gels prepared from reconstituted milk protein concentrate powders of different protein contents. Int. Dairy J. 47:64-71. https://doi.org/10.1016/ j.idairyj.2015.02.005.

Morand, M., A. Dekkari, F. Guyomarc'h, and M.-H. Famelart. 2012. Increasing the hydrophobicity of the heat-induced whey protein complexes improves the acid gelation of skim milk. Int. Dairy J. 25:103-111. https://doi.org/10.1016/j.idairyj.2012.03.002.

Morand, M., F. Guyomarc'h, and M.-H. Famelart. 2011. How to tailor heat-induced whey protein $/ \kappa$-casein complexes as a means to investigate the acid gelation of milk-A review. Dairy Sci. Technol. 91:97-126. https://doi.org/10.1007/s13594-011-0013-x.

Mottar, J., A. Bassier, M. Joniau, and J. Baert. 1989. Effect of heatinduced association of whey proteins and casein micelles on yogurt texture. J. Dairy Sci. 72:2247-2256. https://doi.org/10.3168/jds .S0022-0302(89)79355-3.

Nguyen, H. T., S. Afsar, and L. Day. 2018. Differences in the microstructure and rheological properties of low-fat yoghurts from goat, sheep and cow milk. Food Res. Int. 108:423-429. https://doi.org/ 10.1016/j.foodres.2018.03.040.

O'Brien, B., and T. P. Guinee. 2011. Seasonal effects on processing properties of cows' milk. Pages 598-606 in Encyclopedia of Dairy Sciences. 2nd ed. J. W. Fuquay, P. F. Fox, and P. L. H. McSweeney, ed. Academic Press, San Diego, CA.

Oka, D., W. Ono, S. Ohara, T. Noguchi, and K. Takano. 2018. Effect of heat-induced $\kappa$-casein dissociation on acid coagulation of milk. J. Dairy Res. 85:104-109. https://doi.org/10.1017/ S002202991700084X
Oldfield, D. J. 1996. Heat-induced whey protein reactions in milk: Kinetics of denaturation and aggregation as related to milk powder manufacture. PhD Thesis. Massey University, Palmerston North, New Zealand.

Ozcan, T., J. Lucey, and D. Horne. 2008. Effect of tetrasodium pyrophosphate on the physicochemical properties of yogurt gels. J. Dairy Sci. 91:4492-4500. https://doi.org/10.3168/jds.2008-1292.

Ozcan-Yilsay, T., W.-J. Lee, D. Horne, and J. Lucey. 2007. Effect of trisodium citrate on rheological and physical properties and microstructure of yogurt. J. Dairy Sci. 90:1644-1652. https://doi.org/10 $.3168 /$ jds.2006-538.

Paulsson, M., P.-O. Hegg, and H. B. Castberg. 1986. Heat-induced gelation of individual whey proteins. A dynamic rheological study. J. Food Sci. 51:87-90. https://doi.org/10.1111/j.1365-2621.1986 .tb10842.x.

Ramasubramanian, L., C. Restuccia, and H. Deeth. 2008. Effect of calcium on the physical properties of stirred probiotic yogurt. J. Dairy Sci. 91:4164-4175. https://doi.org/10.3168/jds.2008-1354.

Underwood, J., and M. Augustin. 1997. Seasonal variation in the rheological properties of acid and heat-induced gels made from reconstituted concentrated milk. Aust. J. Dairy Technol. 52:83.

Vasbinder, A. J., A. C. Alting, and K. G. de Kruif. 2003. Quantification of heat-induced casein-whey protein interactions in milk and its relation to gelation kinetics. Colloids Surf. B Biointerfaces 31:115-123. https://doi.org/10.1016/S0927-7765(03)00048-1.

Vasbinder, A. J., F. van de Velde, and C. G. de Kruif. 2004. Gelation of casein-whey protein mixtures. J. Dairy Sci. 87:1167-1176. https: //doi.org/10.3168/jds.S0022-0302(04)73265-8.

Vreeman, H. J., P. Both, J. A. Brinkhuis, and C. Van Der Spek. 1977. Purification and some physicochemical properties of bovine kappa-casein. Biochim. Biophys. Acta 491:93-103. https://doi.org/10 .1016/0005-2795(77)90044-7.

\section{ORCIDS}

Siqi Li @ https://orcid.org/0000-0003-4971-9705

Aiqian Ye @ https://orcid.org/0000-0003-1048-8858

Harjinder Singh ๑ https://orcid.org/0000-0002-8807-3241 